\title{
Acute colchicine toxicity: A case report
}

\author{
Akut kolşisin toksisitesi: Olgu sunumu \\ Çiğdem Dinçkal@ Soner Duman $\mathbb{D}$ \\ Department of Internal Medicine, Ege University Faculty of Medicine, İstanbul, Turkey
}

\begin{abstract}
Colchicine is an alkaloid drug acquired from the autumn crocus (Colchicum autumnale) flower and is used as an antimitotic especially in the treatment of gout and Familial Mediterranean Fever (FMF). Its use in treating some rheumatic diseases (pseudogout, Behcet's disease, sarcoidosis, amyloidosis, etc.) as well as cancer treatment is under research. Although colchicine intoxication rarely occurs, therapeutic doses or suicidal overdose may lead to severe toxicity resulting in death. Clinical symptoms associated with colchicine overdose must be monitored in intensive care as they may show rapid progression. In this report, we present a 22-year-old patient with FMF who died from multiple organ failure shortly after suicidal overdose of colchicine. Keywords: Acute, colchicine, toxicity.
\end{abstract}

öz

Kolşisin, özellikle gut ve Ailevi Akdeniz Ateşi (AAA) tedavisinde kullanılan antimitotik bir ilaç olup Güz Çiğdemi (Colchicum autumnale) çiçeğinden elde edilen bir alkoloid bir ilaçtır. Bazı romatizmal hastalıkların (psödogut, Behçet hastalığı, sarkoidoz, amiloidoz vb.) tedavisinde kullanıldığı gibi kanser tedavisi için de araştırımaktadır. Kolşisin intoksikasyonu nadir görülmekle birlikte terapötik dozlarda veya intihar amaçlı yüksek doz alımında ölüme neden olan ciddi toksisiteye neden olabilir. Yüksek doz kolşisin alımına bağlı klinik bulgular hızla progresyon gösterebileceğinden bu olgular mutlaka yoğun bakım ünitesinde izlenmelidir. Bu yazıda, intihar amaçlı yüksek doz kolşisin alımı sonrası kısa sürede çoklu organ yetmezliğine bağlı kaybedilen 22 yaşında bir AAA olgusu sunuldu.

Anahtar sözcükler: Akut, kolşisin, toksisite.

Colchicine is an alkaloid used in the treatment of acute attacks of Familial Mediterranean Fever (FMF), gouty arthritis and pseudogout. Although acute intoxications are rare, they may present with multiple organ failure. We present our case who was admitted to the emergency department with suicide attempt and acute colchicine poisoning in order to emphasize the steps to be taken in the diagnosis, treatment and follow-up.

\section{CASE REPORT}

A 22-year-old female who was followed up for FMF since 2006 presented to the emergency department with nausea following ingestion of colchicine with suicidal intent was initiated gastric lavage. The patient, who refused treatment, deserted the emergency department and presented to the emergency department again after 24 hours. The patient stated she had ingested 500 tablets of $0.5 \mathrm{mg}$ colchicine and was promptly assessed as $0.8 \mathrm{mg} /$ (body weight: $56 \mathrm{~kg}$ ) with $100 \%$ mortality and admitted to the emergency intensive care unit. Although the patient's vital signs and laboratory results were unremarkable at admission, nausea, abdominal pain, and metabolic acidosis developed during

Received: June 24, 2019 Accepted: July 22, 2019 Published online: October 31, 2019

Correspondence: Çiğdem Dinçkal, MD. Ege Üniversitesi Tıp Fakültesi, İç Hastalıkları Anabilim Dalı, 35100 Bornova, İzmir, Türkiye. Tel: +90 232 - 3742388 e-mail: drcigdemdinckal@gmail.com 


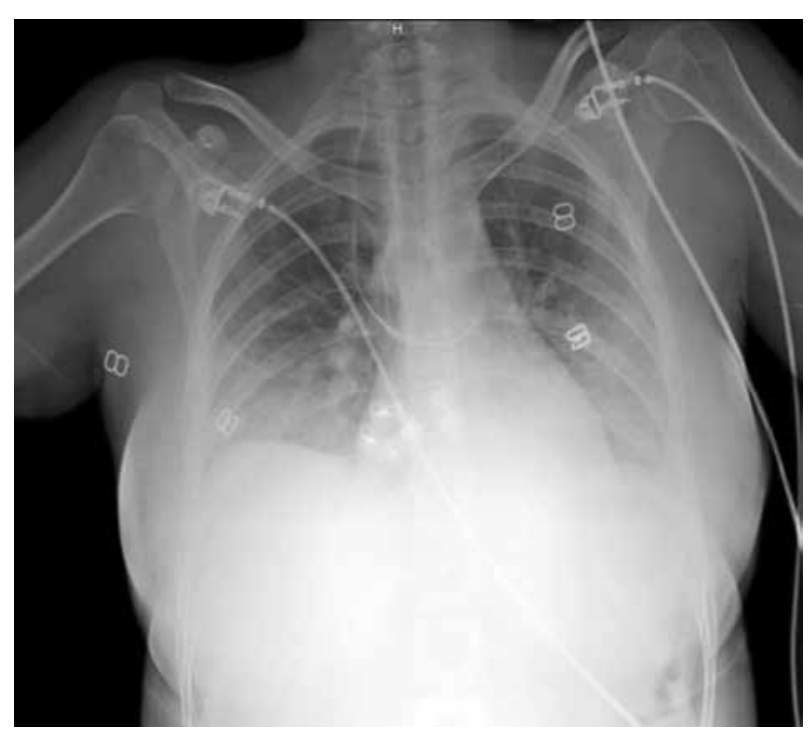

Figure 1. Posterior-anterior chest radiography of the patient.

monitorization, and the patient was consulted to the authors (Department of Internal Medicine) for hemodialysis (HD). Monitorization vitals were as follows: blood pressure $105 / 63 \mathrm{mmHg}$, pulse $116 \mathrm{bpm}$, body temperature $36^{\circ} \mathrm{C}, \mathrm{SO}_{2}$ : 96\%; venous blood gas: $\mathrm{pCO}_{2}: 52.7 \mathrm{mmHg}$, $\mathrm{pO}_{2}$ : $25.9 \mathrm{mmHg}, \mathrm{HCO}_{3}: 18.8 \mathrm{mEq} / \mathrm{L}$, lactate: $5.30 \mathrm{mEq} / \mathrm{L}$, anion gap: 19.6. Physical examination showed the patient was conscious, cooperative, and had full orientation; lung examination did not reveal rales or ronchi but there were decreased respiratory sounds in basal regions; abdominal examination showed widespread tenderness without signs of rebound, defense, peripheral edema, icterus, or flapping tremor. Suboptimal assessment of posterior-anterior lung X-ray (insufficient inspiration because the patient was lying down) did not show metastatic, infectious, or infiltrative changes. Cardiothoracic ratio was normal (Figure 1). Initial electrocardiogram was normal sinus rhythm progressing to sinus tachycardia throughout monitorization. B vitamin complex support was added to intravenous fluid hydration and calcium replacement was administered for hypocalcemia. Laboratory results of the patient during monitorization is shown in Table 1 . Within hours, the patient developed multiple organ failure, ensuing cardiopulmonary arrest. The patient was unresponsive to resuscitation and was lost to exitus 36 hours after admission.

\section{DISCUSSION}

Colchicine poisoning can be potentially lifethreatening due to its high toxicity and lack of specific antidotal treatment. It conventionally manifests as gastroenterocolitis and may lead to multiple organ failure in fatal cases. ${ }^{[1]}$ Although some experimental drugs are under investigation, their use is controversial. ${ }^{[2]}$

Table 1. Laboratory values during patient surveillance

\begin{tabular}{lcccc}
\hline & 0 hours & 12 hours & 24 hours & 36 hours \\
\hline AST (<31 IU/L) & 19 & 60 & 185 & 492 \\
ALT (<34 IU/L) & 16 & 21 & 26 & 62 \\
ALP (35-104 IU/L) & 71 & 89 & 232 & 725 \\
GGT (<38 IU/L) & 14 & 15 & 29 & 46 \\
WBC $\left(10^{3} / \mu \mathrm{L}\right)$ & 10.14 & 15.1 & 25.12 & 26.62 \\
$\mathrm{Hb}(\mathrm{g} / \mathrm{dL})$ & 14 & 15 & 14.6 & 15.3 \\
Plt $\left(10^{3} / \mu \mathrm{L}\right)$ & 360 & 289 & 305 & 156 \\
INR & 1 & - & 1.5 & 2.2 \\
Urea (mg/dL) & 24 & 21 & 22 & 46 \\
Cre (mg/dL) & 0.63 & 0.57 & 0.86 & 1.5 \\
Ca (mg/dL) & 9.7 & 8.30 & 7.2 & 6.4 \\
CRP (mg/dL) & 0.08 & 0.17 & 10.58 & 32.66 \\
Lipase (U/L) & - & 95 & 399 & 211 \\
\hline AST: Aspartate aminotransferase; ALT: Alanine aminotransferase; ALP: Alkaline phosphatase; GGT: Gamma \\
glutamyl transferase; WBC: White blood cell; Hb: Hemoglobin; Plt: Platelet; INR: International normalized ratio; \\
Cre: Creatinine; Ca: Calcium; CRP: C-Reactive protein. & \multicolumn{2}{l}{}
\end{tabular}


Colchicine and metabolites are excreted from the kidneys and liver, and elimination half-life ranges between 20-40 hours. Since colchicine has rapid distribution to tissues and high affinity to intracellular regions, hemodialysis and plasma exchange is ineffective in colchicine poisoning. ${ }^{[3]}$

Minor toxicity occurs when colchicine is ingested under $0.5 \mathrm{mg} / \mathrm{kg}$ doses and has $100 \%$ recovery, while major toxicity at $0.5-0.8 \mathrm{mg} / \mathrm{kg}$ doses has $10 \%$ mortality, and doses above $0.8 \mathrm{mg} / \mathrm{kg}$ reportedly end in cardiogenic shock and death within 72 hours. ${ }^{[4]}$

The most common symptoms of colchicine intoxication over the first 24 hours are nausea, vomiting, and diarrhea. After a 24-hour period, life-threatening complications and multiple organ failure may develop. Central respiratory depression, severe pancytopenia, cardiovascular system complications, and metabolic abnormalities (hypophosphatemia, hyponatremia, hypokalemia, hypocalcemia, metabolic acidosis) are common. ${ }^{[5]}$

Since hemodialysis and hemoperfusion are ineffective due to high distribution volume, aggressive primary decontamination with gastric lavage and activated charcoal is crucial. Signs of poisoning must be diagnosed early and require intense supportive treatment to increase survival. ${ }^{[6]}$ Another promising treatment of colchicine overdose is immunotherapy with colchicine-specific Fab fragments. The treatment is still at its experimental phase, and unfortunately, colchicine-specific antibodies are not yet commercially available. ${ }^{[7]}$

In the first 24 hours, our patient only had symptoms of nausea which progressed to severe abdominal pain and dyspnea over monitorization. Laboratory results initially showed liver failure, which advanced to acute renal failure and hypocalcemia. Increased amylase and lipase as well as leukocytosis and elevated CRP were in favor of drug-induced acute pancreatitis. There are case reports in the literature that have reported rhabdomyolysis associated with colchicine intoxication. Therefore, assessing indicators of muscle damage such as creatinine kinase, myoglobin, and lactic acid dehydrogenase is recommended. ${ }^{[8]}$ In our patient, these markers were not monitored at $0,12,24$ and 36 hours in intensive care.

In conclusion, patients presenting with colchicine ingestion in their latent period should be prioritized and closely monitored. Since dose-related toxicity findings of colchicine are rare and there is still no antidote, we wished to share our case to draw the attention and benefit clinicians.

\section{Declaration of conflicting interests}

The authors declared no conflicts of interest with respect to the authorship and/or publication of this article.

\section{Funding}

The authors received no financial support for the research and/or authorship of this article.

\section{REFERENCES}

1. Nagesh KR, Menezes RG, Rastogi P, Naik NR, Rasquinha JM, Senthilkumaran S, et al. Suicidal plant poisoning with Colchicum autumnale. J Forensic Leg Med 2011;18:285-7.

2. Baud FJ, Sabouraud A, Vicaut E, Taboulet P, Lang $\mathrm{J}$, Bismuth $\mathrm{C}$, et al. Treatment of severe colchicine overdose with colchicine-specific fab fragments, $\mathrm{N}$ Engl J Med 1995;332:642-5.

3. Cheung HT, CantarowWD, Sundharadas G. Colchicine and cytochalasin $\mathrm{B}(\mathrm{CB})$ effects on random movement, spreading and adhesion of mouse macrophages. Exp Cell Res 1978;111:95-103.

4. Weakley-Jones B, Gerber JE, Biggs G. Colchicine poisoning: case report of two homicides. Am J Forensic Med Pathol 2001;22:203-6.

5. Stapczynski JS, Rothstein RJ, Gaye WA, Niemann JT. Colchicine overdose: report of two cases and review of the literature. Ann Emerg Med 1981;10:364-9.

6. Stern N, Kupferschmidt H, Meier-Abt PJ. Follow-up and therapy of acute colchicine poisoning. Praxis (Bern 1994) 1997;86:952-6.

7. Bajramovic-Omeragic L, Calkic L, Hadzic E, Alickovic I. Accidental poisoning with a plant colchicum autumnale: report of two cases. Lijec Vjesn 2015;137:288-91.

8. Arslan MN, Özgün A, Daş T, Kumru D, Şam B, Koç S. Colchicine-Induced Rhabdomyolysis: An Autopsy Case. Am J Forensic Med Pathol 2016;37:57-9. 